\title{
Nursing care for chronic renal patients on hemodialysis
}

\author{
Cuidados de enfermagem ao paciente renal crônico em hemodiálise
}

\author{
Atención de enfermería al paciente renal crónico en hemodiálisis
}

Cecília Maria Farias de Queiroz Frazão ${ }^{1}$, Millena Freire Delgadoํㅜㄴ Marília Gabriela de Azevedo Araújo ${ }^{1}$, Fernanda Beatriz Batista Lima e Silva ${ }^{1}$, Jéssica Dantas de Sá ${ }^{1}$, Ana Luisa Brandão de Carvalho Lira ${ }^{1}$

This study aimed to synthesize the knowledge produced in articles about nursing care for chronic renal patients on hemodialysis. This is an integrative literature review conducted on the databases SCOPUS, CINAHL, PUBMED, LILACS and COCHRANE. The sample consisted of ten articles. Nursing care was categorized and grouped in areas according to NANDA International. The publications occurred between the years 2009 and 2012, prevailing descriptive studies with level VI of evidence. Given the findings, it was identified that nursing care to chronic renal patients is focused on infection prevention, promotion of self-care, guidance to the family and the patient, diet control and the promotion of a comfortable environment. Thus, knowing nursing care provides nurses with subsidies for the development of a specific care plan, targeted on the needs of each individual.

Descriptors: Nursing Care; Renal Dialysis; Renal Insufficiency, Chronic.

Este estudo objetivou sintetizar o conhecimento produzido em artigos sobre cuidados de enfermagem aos pacientes renais crônicos em hemodiálise. Revisão integrativa da literatura, realizada nas bases de dados SCOPUS, CINAHL, PUBMED, LILACS e COCHRANE. A amostra foi composta por dez artigos. Os cuidados de enfermagem foram categorizados e agrupados pelos domínios da NANDA Internacional. As publicações ocorreram entre os anos de 2009 e 2012, prevalecendo estudos descritivos e com nível VI de evidência. Diante dos achados, identificou-se que os cuidados de enfermagem ao paciente renal crônico estão focados na prevenção de infecções, promoção do autocuidado, orientações à família e ao paciente, controle da dieta e promoção de ambiente confortável. Destarte, conhecer os cuidados de enfermagem fornece subsídios ao enfermeiro para elaboração do plano de cuidados específico, direcionado às necessidades de cada indivíduo.

Descritores: Cuidados de Enfermagem; Diálise Renal; Insuficiência Renal Crônica.

El objetivo del estudio fue sintetizar el conocimiento producido en artículos sobre atención de enfermería a los pacientes con insuficiencia renal crónica en hemodiálisis. Revisión integradora de la literatura, en las bases de datos SCOPUS, CINAHL, PubMed, LILACS y Cochrane. La muestra constó de diez artículos. La atención de enfermería fue categorizada y agrupada por los dominios de la NANDA Internacional. Las publicaciones se produjeron de 2009-2012, prevaleciendo estudios descriptivos y con nivel VI de evidencia. Dados los resultados, se identificó que la atención de enfermería al paciente renal crónico se centra en la prevención de infecciones, promoción del autocuidado, orientaciones a la familia y paciente, control de la dieta y promoción de ambiente confortable. Así, conocer la atención de enfermería proporciona subvenciones al enfermero para desarrollo del plan de atención específica, direccionada a las necesidades de cada individuo.

Descriptores: Atención de Enfermería; Diálisis Renal; Insuficiencia Renal Crónica.

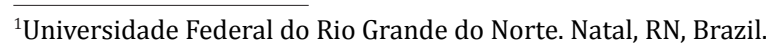




\section{Introduction}

Hemodialysis is one of the forms of treatment for patients who are in the final stage of chronic kidney disease. It is noted in the literature that about one million and two hundred thousand people live under some form of dialysis worldwide ${ }^{(1)}$. Specifically in Brazil, epidemiological studies on the chronic renal disease revealed that the number of patients on dialysis increased significantly in the last eight years ${ }^{(2)}$. Data from 2009 found out that there were approximately 77,589 dialysis patients in Brazil and that the incidence of new patients grows $8 \%$ per year, and that expenses with dialysis and kidney transplant programs are approximately $\mathrm{R} \$ 1.4$ billion per year ${ }^{(2-3)}$.

The Chronic Kidney Disease is defined as an injury to the renal parenchyma and/or functional impairment of the kidney for a period exceeding three months. The reduction of the glomerular filtration rate can be up to $50 \%$ compared to its normal number. When the functional loss of the kidneys worsens there are manifestations, both clinical and laboratory, which make evident the diagnosis, such as: anemia, anorexia, electrolyte, metabolic and hormonal disturbances, and also a deficit in the weight and height development ${ }^{(3-4)}$. The diagnosis is also based on the identification of risk groups: presence of microalbuminuria, proteinuria, hematuria and reduction in glomerular filtration rate, assessed by a laboratory test called serum creatinine clearance ${ }^{(1.3)}$.

The main form of treatment of the chronic renal disease is hemodialysis. This procedure simulates the physiologic glomerular filtration process based on a diffusion mechanism. Thus, patients are connected to a specific machine for a period of up to four hours at a frequency of three days a week ${ }^{(5)}$.

In this context, chronic kidney patients face many conflicts that cause changes in their daily life with restrictions and harm to their quality of life. They experience special conditions requiring hemodialysis and strict control of diet and fluid restriction. Thus, in the illness context and the need for hemodialysis, repercussions affect patients' personal, family and social dimensions ${ }^{(6)}$.

Given the above, it is important that nurses are present in hemodialysis coordinating the team and identifying the needs of each particular patient. In addition, educating patients and their families about the disease and its complications, and providing guidance on treatment plans, with technical and psychological aspects ${ }^{(4)}$. Thus, by understanding that nursing brings care as the essence of its profession and it is therefore in direct contact with patients, the present study aimed to synthesize the knowledge produced in articles about the nursing care provided to chronic renal patients undergoing hemodialysis.

\section{Method}

This is an integrative literature review, which makes the analysis of relevant research that enables to synthesize the knowledge produced about a particular subject, leading to the development of general conclusions about a particular area of study, besides identifying gaps and the need for new studies. This research method includes five steps: identification of the research question; literature search; evaluation of data; analysis of data and presentation of results ${ }^{(7)}$.

The main question of this study was: What is the nursing care provided to chronic renal patients undergoing hemodialysis? The literature search was conducted from April to June 2013 in the following databases: SCOPUS, CINAHL (Cumulative Index to Nursing and Allied Health Literature), PUBMED (National Library of Medicine and National Institutes of Health), LILACS (Latin American \& Caribbean Health Sciences Literature) and COCHRANE. Each database was accessed in a single moment by two researchers simultaneously on different computers with the purpose of selecting the most relevant articles for research, conducting a thorough investigation of the literature.

Controlled descriptors identified in MESH (Medical Subject Headings) were used: Nursing Care, 
Chronic Renal Failure and Hemodialysis. And the Boolean operator AND. The junctions used in the search were: nursing care AND renal dialysis AND renal insufficiency chronic and nursing care AND renal dialysis; Nursing care AND renal insufficiency chronic.

The inclusion criteria defined for the selection of the articles were: articles available in full in the selected databases; available in Portuguese, English and Spanish; articles that addressed nursing care to chronic renal patients on hemodialysis and that answered the research question of this study. The publications present in the sample were selected from the databases, until the month of June 2013, without previous time frame, with the aim of providing comprehensive review about the object of study. And the exclusion criteria were: editorials and letters to the editor.

The search was guided by a protocol, prepared with the following items: theme of review, goal, guiding question, databases to be accessed, descriptors used, their synonyms in English and crossing to be performed. The use of the protocol ensured the agreement between researchers during the conduction of the research.

From the crossing carried out the following results were found: Nursing Care AND renal dialysis AND renal insufficiency chronic (SCOPUS=4; CINAHL=2; PUBMED=101; LILACS=11; Cochrane=0); nursing care AND renal dialysis (SCOPUS $=699$; CINAHL $=27 ; \quad$ PUBMED $=284 ; \quad$ LILACS=26; Cochrane $=34$ ) and nursing care AND renal dialysis (SCOPUS=16; CINAHL=8; PUBMED=182; LILACS=21; Cochrane=22). After applying the inclusion and exclusion criteria, a sample of ten articles was obtained, five from SCOPUS, four from CINAHL and one from LILACS.

For data extraction, an instrument was produced containing year of publication, reference of the article, level of evidence, objective, the study method and nursing care to chronic renal patients on hemodialysis.

Subsequently, studies were categorized according to nursing care, and they were grouped by domains of NANDA International (NANDA-I) ${ }^{(8)}$ : Health promotion, safety and protection, activity and rest, roles and relationships and nutrition. This step had as a process the authors' judgment. The findings were discussed according to the pertinent literature.

\section{Results}

Among the selected publications, one notices that they occurred between the years 2009-2012, with an equivalent number of publications over the years. Thus, it is seen that even without doing a time frame for the search of the articles, the literature presents current studies in this subject. Most studies were carried out in Brazil (5), followed by the United States (2), Norway (1), Denmark (1), and Australia (1).

A prevalence of descriptive studies (6) was observed, having all been classified at level VI of evidence. Studies at this level of evidence (VI), according to the classification Melnyk and FineoutOveholt (2005) derives from descriptive or qualitative approaches. Studies of this nature do not provide the best evidence to guide clinical decision making. However, they provide relevant subsidies on the theme under study and may be the base to clinical research (Figuere 1). 


\begin{tabular}{|c|c|c|c|c|c|}
\hline Id & Year & Title & $\begin{array}{c}\text { Level of } \\
\text { evidence }\end{array}$ & Objective & Method \\
\hline A & 2009 & $\begin{array}{l}\text { A Historical Study of the Integration of } \\
\text { Technology and } \operatorname{Care}^{(9)} \text {. }\end{array}$ & VI & $\begin{array}{l}\text { The role and functions of nurses working with renal } \\
\text { dialysis and transplant teams between } 1915 \text { and } 1970\end{array}$ & Descriptive \\
\hline $\mathrm{B}$ & 2009 & $\begin{array}{l}\text { Nursing for Renal Replacement } \\
\text { Therapies in the Intensive Care Unit: } \\
\text { Historical, Educational, and Protocol } \\
\text { Review }^{(10)} \text {. }\end{array}$ & VI & $\begin{array}{l}\text { To present a protocol of clinical approach for use } \\
\text { in renal replacement therapy in the intensive care } \\
\text { unit that includes: preparation of renal replacement } \\
\text { therapy machine and the patient, the circuit connection, } \\
\text { management and resolution of problems during } \\
\text { treatment, treatment interruption and disconnection of } \\
\text { the circuit. }\end{array}$ & Descriptive \\
\hline $\mathrm{C}$ & 2009 & 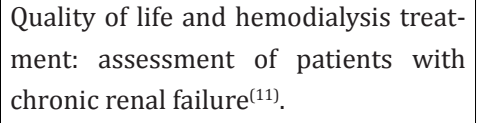 & VI & $\begin{array}{l}\text { To assess the quality of life of patients with chronic renal } \\
\text { disease on hemodialysis, through the instrument Kidney } \\
\text { Disease and Quality of Life Short Form. }\end{array}$ & $\begin{array}{l}\text { Descriptive / } \\
\text { exploratory }\end{array}$ \\
\hline $\mathrm{D}$ & 2009 & $\begin{array}{l}\text { Nursing care for patients on hemodial- } \\
\text { ysis: their instrumental and expressive } \\
\text { dimensions }^{(12)} \text {. }\end{array}$ & VI & $\begin{array}{l}\text { To describe care situations between team members and } \\
\text { patients: to characterize care demands of patients and } \\
\text { analyze dimensions of care in the interactions between } \\
\text { team members and their patients. }\end{array}$ & Qualitative \\
\hline $\mathrm{E}$ & 2010 & $\begin{array}{l}\text { The experience of being } 30-45 \text { years } \\
\text { of age and depending on hemodial- } \\
\text { ysis treatment: a phenomenological } \\
\text { study }^{(13)} \text {. }\end{array}$ & VI & $\begin{array}{l}\text { To describe how patients between } 30 \text { and } 45 \text { years old } \\
\text { face the experience and the addiction to the hemodialysis } \\
\text { treatment. }\end{array}$ & Qualitative \\
\hline $\mathrm{F}$ & 2010 & $\begin{array}{l}\text { Caring nurses: } 24 / 7 \text { nursing, our way } \\
\text { of taking care }{ }^{(14)} \text {. }\end{array}$ & VI & $\begin{array}{l}\text { To outline new ways of caring in dialysis nursing, } \\
\text { weaving a system of care to chronic renal patients. }\end{array}$ & Descriptive \\
\hline $\mathrm{L}$ & 2010 & $\begin{array}{l}\text { Children on dialysis treatment: } \\
\text { nurses' assistance }^{(15)} \text {. }\end{array}$ & VI & $\begin{array}{l}\text { To analyze the assistance of nurses to children on } \\
\text { dialysis treatment. }\end{array}$ & Descriptive \\
\hline $\mathrm{H}$ & 2012 & $\begin{array}{l}\text { Chronic renal children and adolescents } \\
\text { in an educative -therapeutic space: } \\
\text { subsidies to cultural nursing care }{ }^{(4)} \text {. }\end{array}$ & VI & $\begin{array}{l}\text { To understand how children and adolescents with } \\
\text { chronic renal disease experience the illness and therapy, } \\
\text { and describe the actions of educational-therapeutic care } \\
\text { in addressing transcultural nursing. }\end{array}$ & $\begin{array}{l}\text { Qualitative/ } \\
\text { ethnographic }\end{array}$ \\
\hline I & 2012 & $\begin{array}{l}\text { Nurses' perceptions of patients' par- } \\
\text { ticipation in hemodialysis treatment }{ }^{(1)} \text {. }\end{array}$ & VI & $\begin{array}{l}\text { To explore nurses' perception about the participation of } \\
\text { patients over } 75 \text { years of age and their families facing the } \\
\text { hemodialysis treatment. }\end{array}$ & $\begin{array}{l}\text { Qualitative/ } \\
\text { Exploratory }\end{array}$ \\
\hline $\mathrm{J}$ & 2012 & $\begin{array}{l}\text { Ultrafiltration rate as a nursing -sen- } \\
\text { sitive quality indicator in hemodialy- } \\
\text { sis }^{(16)}\end{array}$ & VI & $\begin{array}{l}\text { To discuss the ultrafiltration rate as a sensitive indicator } \\
\text { of the quality of nursing and its significance for health }\end{array}$ & Descriptive \\
\hline
\end{tabular}

Figure 1 - Distribution of articles as to the year of publication, title, level of evidence, objective and method 
The thematic categories about nursing care to chronic renal patients on hemodialysis were established in accordance with the selected studies and grouped by domains present in NANDA- ${ }^{(8)}$. It is highlighted that some articles had more than one category (Figure 2).

\begin{tabular}{|c|c|}
\hline Domain of NANDA-I & Articles* \\
\hline Health Promotion & 5 (Articles: A, F, G, H, I) \\
\hline \multicolumn{2}{|c|}{ To guide the reduction of muscle activity in order to reduce metabolic production of waste. } \\
\hline \multicolumn{2}{|c|}{ To provide information necessary to involve adherence to the treatment by patients and their families. } \\
\hline \multicolumn{2}{|c|}{ To listen carefully to patients concerning their expectations clarifying any doubts. } \\
\hline \multicolumn{2}{|c|}{ To encourage patients to set goals and to seek a better quality of life. } \\
\hline \multicolumn{2}{|c|}{ To encourage the participation of patients and their families in the health-disease process respecting the decisions taken by them. } \\
\hline \multicolumn{2}{|c|}{ To encourage patients' autonomy. } \\
\hline \multicolumn{2}{|c|}{ To provide communication in an appropriate way. } \\
\hline \multicolumn{2}{|c|}{ To establish a dialogue to share information and knowledge about intellectual and/or physical activities. } \\
\hline \multicolumn{2}{|c|}{ To strengthen the capacity for self-care. } \\
\hline \multicolumn{2}{|c|}{ To provide the shared decision making. } \\
\hline Safety and Protection & 5 (Articles: A, B, C, D, J) \\
\hline \multicolumn{2}{|c|}{ To avoid infection through care with the machine and proper handling of the fistula puncture technique. } \\
\hline \multicolumn{2}{|c|}{ To prepare the machine and the patient adequately. } \\
\hline \multicolumn{2}{|c|}{ To manage the treatment from admission until discharge. } \\
\hline \multicolumn{2}{|c|}{ To assess constantly the individual patients' outcomes } \\
\hline \multicolumn{2}{|c|}{ To perform changes of dressings } \\
\hline \multicolumn{2}{|l|}{ To monitor vital signs. } \\
\hline \multicolumn{2}{|c|}{ To observe the bodily manifestations such as: facial expressions compatible with pain, empathy, smile, affection, attention. } \\
\hline \multicolumn{2}{|l|}{ To evaluate ultrafiltration. } \\
\hline \multicolumn{2}{|c|}{ To pay attention to signs of intradialytic hypotension. } \\
\hline Activity / Rest & 3 (Articles: A, B, E) \\
\hline \multicolumn{2}{|c|}{ To provide rest during sessions. } \\
\hline \multicolumn{2}{|c|}{ To keep the patient comfortable. } \\
\hline \multicolumn{2}{|c|}{ To provide conditions to improve sleep. } \\
\hline Roles and relationship & 2 (Articles: F, G) \\
\hline \multicolumn{2}{|c|}{ To educate families about the disease and its implications } \\
\hline \multicolumn{2}{|c|}{ To encourage the establishment of a therapeutic and interpersonal relationship. } \\
\hline \multicolumn{2}{|c|}{ To report about the treatment plan, technical and psychological aspects of the disease. } \\
\hline Nutrition & 2 (Articles: A, D) \\
\hline \multicolumn{2}{|l|}{ To control the diet carefully. } \\
\hline \multicolumn{2}{|c|}{ To check weight in order to detect the cumulative gain between one session and another. } \\
\hline \multicolumn{2}{|c|}{ To advise as to the fluid and food restriction. } \\
\hline To stimulate the eliminati & ract. \\
\hline
\end{tabular}

Figure 2 - Nursing care according to established categories and domains of NANDA-I 


\section{Discussion}

The domains health promotion and safety and protection grouped the largest number of articles totaling five articles for each domain. The health promotion refers to a comprehensive system with biopsychosocial dimensions and multifactorial implications where the focus of care is to maintain control of the quality of life. The domain of security and protection translates the patient's vulnerability which one may relate to patients undergoing hemodialysis ${ }^{(2,8)}$.

In the present study, the care measures listed in the field of health promotion are focused on the identification of individuals' and families' responses to problems related to the chronic renal disease. The self-care deficit is noticeable when the human being judges himself as limited to provide systematic selfcare, requiring support from nursing. Moreover, this deficit occurs when individuals' self-care skills are insufficient to meet their therapeutic needs, in this case, nurses are providers of care ${ }^{(17-19)}$.

Nurses are responsible for making the environment comfortable and suitable for personal care, besides preparing the hemodialysis session carefully, managing the machine, fluid mixing and monitoring vital signs ${ }^{(10)}$.

The second domain, safety and protection, is defined as the individual being free from danger, from physical injury or from damage in the immune system, and the preservation against loss and protection of safety and security ${ }^{(8)}$. In this line of thought, nurses should be aware that the environment in which the patient is should be favorable and thus delivering security, tranquility, comfort.

Due to venipuncture (arteriovenous fistula or central catheter), anemia, leukopenia and other associated chronic diseases such as hypertension and diabetes, the patient is likely to the diagnosis of risk infection. As a result, professionals must use correct puncture techniques, take care of hemodialysis machine and evaluate the filtration rate in order to prevent infections. Additionally, they should manage treatment from admission to discharge, evaluate constantly laboratory tests, dressing changes and observe the physical manifestations, promoting, this way, the safety and protection of the patient on hemodialysis ${ }^{(18)}$.

The fact of being chronically ill can generate conflicting feelings ranging from guilt, lack of motivation and low self-esteem to perform activities of daily life and physical activities ${ }^{(20)}$. The domain activity/rest refers to the production, conservation, expense or balance of energy resources, to do so it is necessary that individuals establish a significant time of rest ${ }^{(8)}$.

To obtain an optimal state of wakefulness, adults require an average of seven to eight hours of sleep per day, however this average is not prevalent among chronic renal patients. The larger the time the patient is undergoing hemodialysis the larger the likelihood that he will develop some sleep disturbance $^{(21)}$. Because of this, it is important for nurses to establish, together with patients and families, goals that enable the improvement of the sleep patterns of these patients, besides providing during sessions of hemodialysis a quiet, comfortable and enjoyable environment, so that they can feel welcomed and safe during sessions.

In the domain roles and relationships, are present diagnoses related to caregiver roles, family relationships and performance of $\operatorname{roles}^{(8)}$. For this category two articles were listed that point as nursing care: educate the family about the disease and its implications; facilitate the establishment of a therapeutic bond; report on the treatment plan, technical and psychological aspects of the disease ${ }^{(4,14)}$.

The patient who is receiving care is understood not only as an individual but as a segment of the family, and when he is hospitalized or ill, the balance and roles of each family member changes. However, it is necessary to meet the needs of the family network, and therefore the bond nurse-patient-family is extremely relevant. A good relationship allows the 
trust and respect to be established ${ }^{(22)}$.

Knowing the patient's family provides subsidies to orient them, solve their questions and ease their anxieties. It also enables the exchange of experience, the bond, and that the information and knowledge occur in a mutual way, promoting a better treatment adherence by the patient, and consequently it improves the quality of life and strengthens family ties $^{(4,14)}$.

For being in direct contact with the patient, his family and other members of the multidisciplinary team, the nurse is responsible for guiding the patient and his family about the disease, its implications and limitations, as well as report about the treatment plan, technical aspects of hemodialysis and possible psychological problems that the patient might experience.

Therefore, it becomes necessary to use communication appropriately, in order to understand the patient through his experiences of being sick or having to live with the disease. It is noteworthy that the interpersonal relationship nurse and patient, in the context of dialysis treatment, due to prolonged contact, favors the establishment of a therapeutic relationship. This enables the patient to trust the nurse, often relieving the process of hemodialysis ${ }^{(1,4)}$.

Accordingly, the shared decision-making is an important tool to promote independence and selfcare of the patient, which leads to two important principles to include him in this task: the principle of benefit, which is based on acts of mercy, kindness and charity; and the principle of autonomy, which is based on equal respect for individuals ${ }^{(15)}$.

Regarding nutrition, chronic renal patients experience several problems due to strict food and water restriction. It is important to evaluate and monitor the nutritional status of these patients, since they are subject to various inter-related conditions such as anorexia, presence of uremic toxins, gastrointestinal disorders and metabolic changes. Notwithstanding the catabolic effect of dialysis, the losses of nutrients in dialysate, several co-morbid conditions including chronic infections, metabolic acidosis and oxidative stress can also contribute to malnutrition, resulting in inadequate food intake. With the start of dialysis, one can notice an improvement in the nutritional status of the patient due to the reduction of uremic symptoms and the establishment of a diet appropriate to their nutritional conditions. However, the risk of malnutrition will be present ${ }^{(23-24)}$. Due to these changes, the adequate supply of nutrients at different stages of treatment favors the maintenance or recovery of the nutritional status, and the prevention or reduction of uremic toxicity. In this way, guiding the patient as to foods he can and cannot eat and the importance of respecting the daily fluid intake is critical so there are no further complications related to retaining metabolites and fluids in the $\operatorname{body}^{(0,23-24)}$.

One of the measures that nurses have to assess whether the patient is correctly following the established diet is weighing him rigorously before and after dialysis. Keeping the patient's chart updated so that they could make a weekly comparison of weight gain. Moreover, it is also important to investigate the bowel eliminations ${ }^{(9)}$.

Thus, the daily contact with the patient on hemodialysis favors care actions, leading to interrelationship between the caregiver and the person receiving care. Therefore, knowledge allows the nurse to minimize problems arising from chronic diseases, seeking strategies to help the patient to cope with the illness, making him able to take an active role in his treatment and creating bonds. Furthermore, it is evident the importance of nursing care to promote health to chronic renal patients, mainly due to the limitations and changes that the disease and treatment cause in his life.

\section{Conclusion}

This review has presented as the main nursing interventions to hemodialysis patient the prevention to infections, promotion of self-care, guidance to 
the family and to the patient, diet control, and the promotion of a comfortable environment. From the results of the study, it was noticed that the nursing care provided to chronic renal patients on hemodialysis are related to the domains of NANDA-I: health promotion, safety and protection, activity/rest, roles and relationships and nutrition.

The nursing interventions identified for these patients, as well as their relationship to the domains of NANDA-I allow one to list the needs most commonly found in them. They subsidize the organization of care plans that lead to better outcomes, in addition to favoring the inter-relationship between the nurse, the patient and the family, which is a key tool for the continuity of nursing care and that contributed positively to the completion of the recovery process of the patient's health.

Hence, the results allow the targeting of routine activities in hemodialysis institutions, focused on the needs that often affect renal patients, contributing greatly to the direction of nursing care according to the patient's needs and the domains of NANDA-I.

Given the results, it was perceived as a limitation a large number of descriptive studies addressing nursing interventions. Thus, the production of new studies with higher levels of evidence should be encouraged.

\section{Collaborations}

Frazão CMFQ, Delgado MF, Araújo MGA, Silva FBBL and Sá JD contributed to the conception, organization, analysis and interpretation of data and drafting of the article. Lira ALBC contributed to the conception, guidance, critical revision and final approval of the version to be published.

\section{References}

1. Pennafort VPS, Queiroz MVO, Jorge MSB. Children and adolescents with chronic kidney disease in an educational-therapeutic environment: support for cultural nursing care. Rev Esc Enferm USP. 2012; 46(5):1057-65.

2. Terra FS, Costa AMDD, Ribeiro CCS, Nogueira CS, PradoJP, Costa MD, etal. O portador de insuficiência renal crônica e sua dependência ao tratamento hemodialítico: compreensão fenomenológica. Rev Bras Clin Med. 2010; 8(4):306-10.

3. Bastos MG, Bregman R, Kirsztajn GM. Doença renal crônica: frequente e grave, mas também prevenível e tratável. Rev Assoc Med Bras. 2010; 56(2):248-53.

4. Moreira DS, Vieira MRR. Crianças em tratamento dialítico: A assistência pelo enfermeiro. Arq Ciênc Saúde. 2010; 17(1):27-34.

5. Karkar A. Modalities of Hemodialysis: Quality Improvement. Saudi J Kidney Dis Transpl. 2012; 23(6):1145-61.

6. Valle LS, Souza VF, Ribeiro AM. Estresse e ansiedade em pacientes renais crônicos submetidos à hemodiálise. Estud Psicol. 2013; 30(1):131-8.

7. Souza MT, Silva MD, Carvalho R. Revisão integrativa: o que é e como fazer. Einstein. 2010; 8(11):102-6.

8. Herdman TH. NANDA International Nursing Diagnoses: definitions and classification 20122014. Oxford: Wiley-Blackwell; 2012.

9. Hoffart N. Nephrology Nursing 1915-1970: a historical study of the integration of technology and care. Nephrol Nurs J. 2009; 36(2):181-91.

10. Baldwin I, Fealy N. Nursing for Renal Replacement Therapies in the Intensive Care Unit: Historical, Educational, and Protocol Review. Blood Purif. 2009; 27(2):174-81.

11. Cordeiro JABL, Brasil VV, Silva AMTC, Oliveira LMAC, Zatta LT, Silva ACCM. Qualidade de vida e tratamento hemodialítico: avaliação do portador de insuficiência renal crônica. Rev Eletr Enf. [periódico na Internet] 2009 [citado Jun 11]; 11(4):785-93. Disponível em: http://www.fen. ufg.br/fen_revista/v11/n4/pdf/v11n4a03.pdf

12. Rezende RC, Porto IS. Cuidado de enfermagem para clientela em hemodiálise: suas dimensões instrumentais e expressivas. RevEletr Enf. [periódico na Internet] 2009 [citado Jun 11]; 11(2):266-74. Disponível em: http://www.fen. 
ufg.br/fen_revista/v11/n2/v11n2a05.htm

13. Herlin C, Wann-Hansson C. The experience of being 30-45 years of age and depending on haemodialysis treatment: a phenomenological study. Scand J Caring Sci. 2010; 24(4):693-9.

14. Furtado AM, Pennafort, VPS, Silva LF, Silveira LC, Freitas MC, Queiroz MVO. Cuidar permanência: enfermagem 24 horas, nossa maneira de cuidar. Rev Bras Enferm. 2010; 63(6):1071-6.

15. Aasen EM, Kvangarsnes M, Heggen K. Nurses' perceptions of patient participation in hemodialysis treatment. Nurs Ethics. 2012; 19(3):419-30.

16. Lindberg M, Ludvigsen MS. Ultrafiltration rate as a nursing-sensitive quality indicator in hemodialysis. Int J Nurs Stud. 2012; 49:1320-4.

17. Sousa MNA, Sarmento TC, Alchieri JC. Estudo quantitativo sobre a qualidade de vida de pacientes hemodialíticos da Paraíba, Brasil. Rev CES Psic. 2011; 4(2):1-14.

18. Bezerra MLR, Ribeiro PRS, Sousa AA, Costa AIS, Batista TS. Diagnósticos de enfermagem conforme a teoria do autocuidado de Orem para pacientes em tratamento hemodialítico. Rev Ciênc Ext. 2012; 8(1):60-81.

19. Vitor AF, Lopes MVO, Araujo TL. Teoria do déficit de autocuidado: análise da sua importância e aplicabilidade na prática de enfermagem. Esc Anna Nery. 2010; 14(3):611-6.
20. Fernandes MGM, Pereira MA, Bastos RAA, Santos KFO. Diagnósticos de enfermagem do domínio atividade/repouso evidenciados por idosos em tratamento hemodialítico. Rev Rene. 2012; 13(4):929-37.

21. Guimarães CKD, Alves DA G, Guimarães LHCT. Avaliação da qualidade e quantidade do sono em pacientes renais crônicos submetidos à hemodiálise. Rev Neurocienc. 2011; 19(4):60913.

22. Burille A, Silva DA, Macagnam KL, Zillmer JGV, Schwartz E, Santos EB. Construindo caminhos para assistir famílias: um desafio para acadêmicos de enfermagem. Ciênc Cuid Saúde. [periódico na Internet] 2008 [citado 2013 ago 20]; 7(supl 2). Disponível em: http://periodicos.uem.br/ojs/ index.php/CiencCuidSaude/article/view/6686

23. Santos ACB, Machado MC, Pereira LR, Abreu JLP, Lyra MB. Associação entre qualidade de vida e estado nutricional em pacientes renais crônicos em hemodiálise. J Bras Nefrol. 2013; 35(4):27988.

24. Barros A, Costa BE, Poli-de-Figueiredo CE, Antonello IC, D'avila DO. Nutritional status evaluated by multi-frequency bioimpedance is not associated with quality of life or depressive symptoms in hemodialysis patients. Ther Apher Dial. 2011; 15(1):58-65. 